\title{
The Perceptions and Determinants of Auditing and Reporting Quality in the Asia-Pacific Region
}

Pran K. Boolaky, Griffith University, Teerooven Soobaroyen, Essex University, Reiner Quick, Technical

University of Darmstadt

\section{${ }^{*}$ Correspondence}

Pran K. Boolaky, Griffith University, 170 Kessels Road, Nathan, QLD 4111, Australia. Tel: +61 73735 7111; email:

p.boolaky@griffith.edu.au

\begin{abstract}
A country's institutional environment significantly influences perceptions of auditing and reporting quality (ARQ) at the national level. Relying on a relatively unique measure of ARQ, collated by the World Economic Forum (WEF), we evaluate the influence of nine key isomorphic pressures on the ARQ in 26 Asia-Pacific countries. The results suggest that six of these (the efficacy of the corporate board, securities exchange regulations, reliance on professional management, protection of minority interests, adoption of international financial reporting and prevalence of foreign ownership) have a highly significant influence on the perception of ARQ whereas adoption of international standards on auditing is only moderately significant. However, contrary to expectations, our findings do not support the argument that the efficiency of legal frameworks and political systems significantly influence the perceptions of auditing and reporting quality in the AsiaPacific region. These results should be of use to investors and the accounting profession in evaluating economic environments.

\section{Summary at a glance}

This paper evaluates the influence of nine key isomorphic pressures on auditing and reporting quality (ARQ) in 26 AsiaPacific countries. Results suggest that six of these (the efficacy of the corporate board, securities exchange regulations, reliance on professional management, protection of minority interests, adoption of international financial reporting and prevalence of foreign ownership) have a highly significant influence on the perception of ARQ whereas adoption of international standards on auditing is only moderately significant.
\end{abstract}

This paper investigates the determinants of auditing and reporting quality (ARQ) in 26 countries in the Asia-Pacific region. The extant literature treats differences in national accounting quality as a function of the legal/political system, strength of equity markets, tax system, corporate governance structures, ownership patterns and adoption of international standards, and this is empirically tested using mainly corporate-level data and other related proxies, principally from a preparer's or analyst's perspective (Barth et al. 1999, 2006; Leuz et al. 2003; Soderstrom and Sun 2007; Cheong et al. 2010; Kabir et al. 2010; Houque et al. 2012; Ahmed et al. 2013a, 2013b; Bajra and Cadez 2017). However, few studies to date have sought to provide evidence of how ARQ is perceived by users at the national level and whether some or all of the factors mentioned above can lead to cross-national variations in auditing and reporting quality.

Our central thesis is that such variations in ARQ will be due to different levels of adoption and implementation of International Financial Reporting Standards (IFRS) and International Standards on Auditing (ISA), legal systems including laws related to investor protection, the extent of professional management, securities regulations and the corporate governance practices of a country (La Porta et al., 1997, 2000; La Porta 2006; Leuz et al. 2003; Schockaert and Houyoux 2007; WEF 2009; Nobes 2010; 
Lont and Wong 2010; Boolaky 2012; Houque et al. 2012; Christensen et al. 2014; Boolaky and Cooper 2015). However, none of these studies explicitly considers the role of ISA and IFRS adoption and the type of political system on ARQ.

We extend the literature by including these three previously mentioned variables as potential factors influencing ARQ. In doing so, we depart from previous studies such as Leuz et al. (2003), Leuz (2010), Houqe et al. (2012) and Ahmed et al. (2013a, $2013 \mathrm{~b}$ ) in the following three ways. First, we use a country-level measure for ARQ from the perspective of a broad constituency of users. Second, our sample of countries includes 16 countries not considered in Leuz et al.'s (2003) study and other recent studies (e.g., Houqe et al. 2012; Ahmed et al. 2013a). Third, instead of using relatively broad clusters of countries on the basis of similar legal and institutional characteristics (e.g., Leuz et al. 2003; Leuz 2010), we consider the individual effects of a number of country variables on ARQ and also assess country fixed effects and year fixed effects. Finally, we categorise the selected countries into developed and developing countries to ascertain if the drivers of ARQ are the same and offer any reasons for this, if applicable.

In this regard, we rely on a relatively unique cross-national data set collated on an annual basis by the World Economic Forum (WEF) as part of its initiative to publish regular Global Competitiveness Reports for each nation state. The use of the WEF in the accounting literature is fairly recent but emerging (see Houqe et al. 2012; Boolaky and Cooper 2015). Amongst the various themes collected from a survey of corporate leaders, the WEF seeks to evaluate their perceptions of ARQ in their home country. This score varies significantly between countries and arguably provides an alternative, albeit broader, dimension of 'accounting quality' compared to the accruals-related proxies used in the mainstream literature and the limitations of such measures thereof (e.g., refer to McNichols 2002; Dechow and Dichev 2002; Leuz et al. 2003; Chua and Taylor 2008; Hribar et al. 2010; Ahmed et al. 2013a; Kabir and Laswad 2015). Whilst a measure of how users actually 'rate' the quality of accounting and reporting might be seen as subjective, such perceptions do influence users in their decision-making processes (e.g., equity investments, mergers and acquisitions and debt financing), specifically in terms of the extent to which their judgement would be swayed by available accounting information. We therefore contend that this measure provides an opportunity to examine 'auditing and reporting quality' primarily from a user's perspective by relying on a metric which is not beholden to the assumptions underlying estimations of accruals-based measures and by the influence of management, governance and related firm-specific factors (e.g., as highlighted by Ahmed et al. 2013a; Hoang et al. 2017).

To develop an explanatory model of the cross-national variations in ARQ, we are informed by the broad tenets of the neoinstitutional perspective (Di Maggio and Powell 1983; Scott 2001; Judge et al. 2010; Beckert 2010; Rahman et al. 2010). We contend that differences/similarities in the way ARQ is perceived are likely to be associated with the similarities/differences in the institutional arrangements prevailing in the different jurisdictions, whether at an organisational, state or societal level (Scott 2001). We posit that a high level of ARQ indicates that the respondents perceive accounting quality to be not only reflective of the technical features of specific accounting and reporting practices but also that it is appropriate to the context of the jurisdiction and therefore deemed trustworthy (Judge et al. 2010). This argument is consistent with the mainstream international accounting literature which suggests that there are a number of contextual factors, often labelled generically as 'institutional' (e.g., Nobes 1998; Soderstrom and Sun 2007; Leuz 2010; Houqe et al. 2012), which would impact on the quality of accounting information. Arguably, these institutional arrangements mediate the nature of the incentive arrangements and the agency relationships occurring at the firm level, as illustrated by the different analyses of key Asian nations (e.g., Ball et al. 2003; Rahman et al. 2010). As suggested by Ball et al. (2003: 258), ' $\ldots$. [accounting] quality is what a country's institutional environment demands'.

We rely on the WEF dataset and country-level data over nine years (2007--2015) for 26 countries and run a multiple regression to investigate the determinants of ARQ. Our analysis suggests that the adoption of ISA is only a moderately significant factor. Political system(s) is positively but not significantly associated with ARQ in the Asia-Pacific region. The finding on the adoption of IFRS corroborates the expectations initially put forward, for example, by Ball et al. (2000), Soderstrom and Sun (2007), Cheong et al. (2010) and Baboukardos and Rimmel (2014). Likewise, the adoption of ISA is also associated with ARQ in line with prior studies such as Boolaky (2012) and Christensen et al. (2014). The authors suggest that investors are more reliant on the audit report if the latter provides information on key audit matters as required by the revised ISA on audit reporting. Our paper contributes to the literature and debate on ARQ in the following ways. First, there has been a sustained interest in the Asia-Pacific region as a high growth area and one where there is a variety of political and legal arrangements that may influence accounting quality (Ball et al. 2003). The region's emerging markets powered the global economy out of recession in 2010. International capital flows substantially increased in 2010 followed by a rise in regional equity-market capitalisation by $19.2 \%$. To that effect the IMF forecasted a slight growth to 5.5\% in GDP for 2014 and 2015 (Regional Economic Outlook 2014: 5). According to the 
Regional Economic Outlook (2014) corporate leverage for the region rose because companies tried to take advantage of still favourable global liquidity conditions, whilst it is acknowledged that recent concerns have emerged as to the sustainability of corporate growth rates, particularly in the case of China. An understanding of the perceived auditing and reporting quality in this region would be of interest to a growing number of investors and stakeholders. Second, the overwhelming majority of prior accounting quality studies have focused on firm-level data and, as a result, have tended to emphasise agency relationships to explain cross-national differences in accounting quality. Yet, Rahman et al. (2010:2) argue that agency theory is only applicable in an institutional setting (or settings) where the agency relationships between ownership, debt and management are clearly explicable, but there have been indications that this is not necessarily the case in many Asia-Pacific countries. Methodologically, this has implied the selection of a sample of (usually listed and non-financial) companies whose accounting choices and use of specific accounting standards are then linked to the mainstream indicators of accounting quality, that is, abnormal or discretionary accruals and timely loss recognition (e.g., Ball et al. 2003; Leuz et al. 2003; Rahman et al. 2010; Ahmed et al. 2013b). This has led to a rather one-dimensional picture of accounting quality in the literature. By adopting the WEF's 'perception of the strength of auditing and reporting' as a measure of ARQ, it has been possible to assess accounting quality independently of firm-level accounting metrics and discretionary accounting behaviour, and conclude that the adoption of accounting and auditing standards (e.g., IFRS and ISA) contribute to higher/lower perceptions of auditing and reporting quality.

Third, we depart from past studies in a number of ways by applying institutional theory to develop a conceptual model explaining the perceptions of ARQ at a macro level, using a unique set of country-level data that have not been extensively used in the literature so far (notable exceptions being Houque et al. 2012; Boolaky and Cooper 2015) and contrary to extant literature that relies on firm-level data and La Porta et al.'s (1998) dataset which have some shortcomings (see Kaufmann et al. 2007; Spamann 2010). In particular, we examine whether the adoption/implementation of IFRS and ISA and political system(s) explain differences in national ARQ between countries located in the Asia-Pacific region.

\section{ARQ: Theoretical Framework and Hypotheses}

ARQ is the perceived extent to which auditing and accounting practices provide reliable information and ensure access to information in a timely manner (WEF 2010: 4). It is measured from a survey of a sample of top management leaders from companies in 133 countries to ascertain their opinions on the level of auditing and reporting quality in their country (WEF 2009: 62). It is an actual, albeit subjective, assessment of the auditing and financial reporting standards to reflect company financial performance using a seven-point Likert-type scale. A weighted average of the scale reported by the respondents in a country is measured as the ARQ score. A review of the various Global Competitiveness Reports (GCR) of the WEF indicates that ARQ significantly varies across countries. There are a few studies on the variation in ARQ cross-nationally (Boolaky and O'Leary 2011; Boolaky 2012; Boolaky and Cooper 2015). The findings are that some determinants are similar, but their magnitude varies between Europe and Asia. However, these studies are based only on one year's ARQ data (2009) and do not account for the recent changes in ARQ and in the adoption of international accounting and auditing standards in the Asia-Pacific region.

\section{The neo-institutional perspective}

The neo-institutional perspective suggests that organisations and their actors are influenced by pressures from their institutional environments (Di Maggio and Powell 1983). Di Maggio and Powell (1983) describe these different pressures as forces and classify them into coercive, mimetic and normative pressures. They further argue that coercive pressure is more significant when corporations are subject to laws, regulations and actual regulatory enforcement. The perceptions towards the accounting quality in a country could therefore be associated with the power exerted by the legal system when dealing with cases involving accounting failures and investor protection (Rahman et al. 2010: 5; Leuz 2010; Houqe et al. 2012). Mimetic pressures occur when a corporation mimics the behaviour of other successful corporations or trading partners in a bid to improve its own legitimacy and acceptance. Finally, normative isomorphism occurs when individuals are trained under similar educational systems and tend to engage in similar conventional practices. Therefore, a corporation that draws from a standard pool of professional staff will be able to enhance their systems and practices because their ability to harmonise and enhance accounting quality may be greater. The three types of pressures are important to our understanding of ARQ and its determinants. Judge et al. (2010) adopt these concepts in a cross-national study that seeks to explain national IFRS adoption in 132 countries. They argue that the extent of IFRS adoption (as 
defined by Deloitte, 2007--2015) is the result of coercive, mimetic and normative pressures. Judge et al. (2010) target one variable for each type of institutional pressure, respectively foreign aid, import penetration and education level, and find all three variables to be significant in the presence of two control variables (market capitalisation and GDP growth). The authors also find that traditional cultural variables (Hofstede 1980) and security law factors (La Porta et al. 2006) are not significant in explaining the extent to which a country will adopt IFRS. Crucially, however, the measure of IFRS refers only to the 'official' level of implementation and not to the level at which it is actually implemented (or perceived to be implemented) in each country (Bradbury and Mear 2017). To some extent therefore, our study can be seen as an extension of Judge et al.'s (2010) study in that it is able to consider the consequences of IFRS adoption (or non-adoption) in terms of how accounting quality is actually perceived by users in their respective countries.

\section{IFRS and ARQ}

The aim of IASB-led regulation has been to harmonise accounting systems and practices and make accounting information more comparable and reliable. Accounting standards, legal and political systems affect accounting and reporting quality (Soderstrom and Sun 2007; Ding et al. 2007). When a country shifts from its own Generally Accepted Accounting Principles (GAAP) to IFRS, this is likely to affect financial reporting practices, but the quality of accounting will continue to differ among countries because there are other determinants which influence reporting practices. Abongwa (2005) argues that despite the advent of international-level regulation (IFRS and ISA), convergence between the Financial Accounting Standards Board (FASB) and the International Accounting Standards Board (IASB) has not been achieved because of differences in environmental and cultural factors. In particular, in a study of 46 countries relying on company-level data on discretionary accruals, Houqe et al. (2012) find that investor protection and IFRS adoption do not individually lead to improvements in accounting quality and it is in fact their interaction which does so. There are nonetheless strong pressures from the World Bank and other supra-national bodies for convergence and for countries to adopt IFRS and ISAs as a means to enhance the legitimacy of the country and of its companies as an attractive destination for foreign investors (Chua and Taylor 2008).

Cheong et al. (2010) investigated whether IFRS adoption in Australia, New Zealand and Hong Kong has led to an improvement in forecast accuracy in firms that have used IFRS as opposed to the pre-IFRS periods. The authors argue that the mandatory adoption of IFRS entails greater transparency because IFRS requires firms to impart better quality information in the financial statements. Similarly, Baboukardos and Rimmel (2014) sought to provide evidence on fair value accounting and purchased goodwill in the Greek context. They contend that purchased goodwill reported in the accounts of Greek listed companies is value-relevant and infer that fair value accounting will produce relevant information even if the reporting environment is not conducive to IFRS application. They further argue that failure to comply with IFRS disclosure requirements impairs the accounting numbers reported in the financial statements.

Lastly, Ahmed et al. (2013a) carried out a meta-analysis of studies analysing the effects of IFRS adoption, specifically on financial reporting quality (value relevance and discretionary accruals) and quality of information for analysts. On the basis of an analysis of about 50 studies from various countries (primarily European countries and a few from the Asia-Pacific region), the authors conclude that IFRS adoption has led to increases in the relevance of earnings but not of the book value of equity, albeit that results with regards to the latter vary in relation to the country's legal system. In addition, the level of discretionary accruals has not declined whilst the analysts' forecast accuracy has improved post-IFRS adoption. Collectively, these insights highlight the qualityenhancement features of IFRS adoption but the improvements are not uniform and are often driven by legal and enforcement implications. Furthermore, the assessment of accounting quality is typically based on the preparers' perspective, with the exception of studies relying on analyst forecasts. Our study instead considers the perceptions from a broader constituency of informed users and from the perspective of normative and mimetic pressures, we contend that perceptions of accounting quality would be linked to the extent of IFRS adoption, as suggested by several authors (e.g., Chua and Taylor 2008; Judge et al. 2010; Houqe et al. 2013; Ahmed et al. 2013a, 2013b). We therefore posit that:

H1: There is a positive significant association between IFRS and perceptions of ARQ.

ISA and ARQ 
Compared to the significant body of work on IFRS adoption, there is very little evidence on the impact of ISA adoption on the quality of auditing and reporting. A few studies have only provided evidence as to the emergence of ISA globally (e.g., Humphrey and Loft 2013) and at the country level (e.g., Brody et al. 2005; Dellaportas et al. 2008; Mennicken 2008; Al-Awaqleh 2010; Boolaky and Soobaroyen 2017). The latter have been mainly concerned with the challenges facing auditors and regulators in adopting ISA and do not emphasise the actual consequences for accounting quality. Simunic et al. (2014) contend that national auditing standards tend to reflect a country's business environment and legal systems but recently, the authors assert that more countries have tended to adopt a more uniform set of standards, and in particular, it is predicted that ISAs will be adopted (with or without modifications) by countries with similar legal characteristics, with the aim of improving audit and reporting outcomes. Lastly, following the approval of a revised standard for a new reporting model by the IAASB ${ }^{1}$ in 2014 , Christensen et al. (2014) conducted an experimental study to examine how nonprofessional investors react to a key audit matter (KAM) paragraph in the new audit reporting model. The experiment was performed on a number of business school graduates (nonprofessional investors) who invested in stocks and analysed company financial data. The authors suggest that an audit report with a KAM paragraph is more informative to investors and hence more likely to change their investment decisions as opposed to investors who use a standard audit report or investors who receive the KAM as part of the management's footnotes. Since the revised standard became effective in 2016, the impact on professional investors can only be truly known by observing their investment decision after 2016. However, Christensen et al.'s (2014) study provides rare empirical evidence of the impact of the new audit reporting on users' perceptions. Based on the above, our hypothesis is:

$\mathrm{H} 2$ : There is a positive significant relationship between ISA adoption and perceptions of ARQ.

\section{Political system (level of democracy) and ARQ}

It is often argued that accounting standards are also the product of a political decision (Belkaoui 1983; Larson and Kenny 1995; Hassabelnaby et al. 2003; Barbue 2004) and this is to some extent the case for auditing standards. Belkaoui (1983) contends that civil freedom in a country is a critical success factor in the development of accounting and auditing practice, since the latter is associated with an increased level of transparency and accountability for companies and other organisations. On the one hand, a country with a low level of political freedom, freedom of choice in all forms such as freedom of expression, freedom of association and independent media, signals limited access to information (Houque et al. 2012) with a concomitant impact on the availability and quality of accounting and reporting. On the other hand, countries with higher levels of political freedom typically rely on an informed and aware citizenry to enable the exercise of voting and other political rights. We therefore argue that the more democratic a country is, the greater the transparency, and hence one would expect higher levels of perceived ARQ. In contrast, Shleifer and Vishny (1997) suggest that free media have been a setback for a few post-communist countries that have attempted to introduce open market economies. Other authors contend that political stability impacts on the economy and as a result has an influence on accounting development, including auditing (Larson and Kenny 1995). Rahman (1997) emphasises the importance of political power in the development of accounting and infers that those with power would be able to influence the evolution of accounting standards as well as their adoption. Based on the above, we therefore hypothesise that:

H3: There is a positive association between the level of democracy and the perceptions of ARQ.

\footnotetext{
${ }^{1}$ The revised standard was approved in September 2014 and planned for issue in 2015 with effect from 2016 calendar year-end audits. This new reporting model requires additional information to be included in the audit report, namely: (1) name of engagement partner; (2) statement of auditor's independence; (3) key audit matters; (4) increased information on going concern; (5) auditor's responsibility for 'other' information; and (6) placement of auditor's opinion first within the report. A similar move was followed by the US PCAOB in August 2013 but contrary to IAASB, the former did not propose any change in the format and statement of independence. Key audit matters are referred to as critical audit matters. Likewise, the EU also recommended a new audit reporting model as part of its broad audit reform legislation in April 2014.
}

Comment [SH3]: Author: this reference is not listed in the References. Please either delete it from the text or provide full reference details 


\section{Research Methods}

\section{Data}

This study used several sources to collect data, namely: 1) the Global Competitiveness Reports (GCR, 2007--2015) of the WEF; 2) the World Bank Report (2002-2015) on the Observance of Standards and Codes for the Asia-Pacific countries (ROSC); 3) the International Federation of Accountants Compliance Program Report (www.ifac.org); 4) the Economic Intelligence Unit's (EIU) Democracy Index Report (2016); and 5) Deloitte's Report on IAS implementation by country (2007--2015) (see Cornelius 2005; Nobes and Parker 2008; Hegarty et al. 2009; Boolaky 2012)

The WEF draws its findings from authoritative data sources (e.g., the World Bank, the United Nations) and an Executive Opinion Survey. Appendix A depicts the structure of the questions, including the content, criterion and construct validity of the response scale in the survey. The survey addresses 12 pillars of the Global Competitiveness Index. Each pillar contains a number of indicators (see Appendix B for a list of the 12 pillars of competitiveness). The indicators under each pillar are not mutually exclusive and one may influence the other (WEF 2009). Based on extant literature only six factors from Pillars 1,6,8 and 10 are considered as principal determinants of ARQ. We consider these six factors as control variables and add three additional variables of interest from the other sources to perform the statistical analysis. They are described below.

\section{Sampling, data reliability and validity}

The sampling is stratified based on the company's size and sector of activity and ensures that it comprises a sufficient number of large firms and represents the main sectors of an economy. Appendix $\mathrm{C}$ shows the sample size by country over nine years from 2007--2015. Reliability and validity test(s) were performed at both the collection and processing stages and constantly reviewed $;{ }^{2}$ WEF surveys with completion rates of less than $50 \%$ were excluded; a multivariate outlier analysis was applied to the data using the Mahalanobis distance technique and followed by a univariate outlier test at country level for each question (GCR 2009: 49--51; 61--63). With regards to validity, the questionnaire in the opinion survey was constructed using the main types of validity, namely: content, criterion and construct validity (Stangor 2006). Further evidence of the reliability and validity of the WEF dataset is its use for the conduct of empirical studies as well as bases for policy decisions and institutional reforms (GCR 2009: xi).

The GCR of the WEF is used as a main data source for a number of reports ${ }^{3}$ prepared by national, regional and international organisations as well as in the economics literature, but its use has so far been very limited in accounting (see Francis et al. 2001; Black and Carnes 2006; Boolaky 2012; Boolaky and Cooper 2015; Houqe et al. 2012). For instance, Black and Carnes (2006) use the data to analyse the association between macroeconomic factors and accounting systems whereas Francis et al. (2001) rely on similar data to study the relationship between investor protection laws, accounting and auditing. Boolaky (2012) and Boolaky and Cooper (2015) use the same dataset for 2009 to investigate the determinants of the strength of auditing and reporting standards in Europe, and Houqe et al. (2012) rely on several WEF measures to investigate the determinants of the quality of accounting earnings (as measured by discretionary accruals).

The International Federation of Accountants (IFAC) classifies countries on the basis of ISA adoption using four groupings ${ }^{4}$ whereas Deloitte (2007--2015) classifies countries on the basis of the 'Use of IFRSs', also using four groupings. ${ }^{5}$ Using data from

${ }^{2}$ An internationally renowned survey consultancy in collaboration with the WEF and the Institute of Strategy and Competitiveness at the Harvard Business School were involved in the survey methodology and design.

${ }^{3}$ The Global Information Technology Report, The Travel and Tourism Competitiveness Report, The Global Enabling Trade Report, The Gender Gap Report and The Financial Development Report. The data are also used to elaborate the renowned Corruption Perception Index and the International Bribe Index.

${ }^{4}$ (1) ISAs required by law or regulation; (2) ISAs adopted by the national standard setter to be used in the country; (3) National Standards are ISAs, but any modifications(s) to meet local requirements are stated to be in line with the spirit of the International Auditing and Assurance 
these two sources we re-classify the countries into four categories as follows: Category A for Group 1, Category B for Group 2, Category C for Group 3 and Category D for Group 4. The IFAC Report on Audit Quality (IFAC 2014) stipulates that the criteria for high-quality audit standards should be that they are: (1) established by an International Body; (2) legally enforceable; (3) capable of unambiguous translation and consistent interpretation. The reason for assigning Group 1 Category $\mathrm{A}$ is due to the fact that ISAs and IFRSs are mandatory. Therefore, it is expected that ARQ would be higher compared to countries where ISAs/IFRSs are not mandatory and where companies would be using national auditing and/or accounting standards. Table 1 reports the change in the status of IFRS and ISA adoption of the 26 countries in 2007, 2011 and 2015. These changes are discussed in the next section.

\section{Explanatory models}

In order to evaluate the extent to which these institutional-led factors influence ARQ at the country level, we rely on a regression analysis. We begin by pooling all the countries together to determine the impact of the variables of interest (Model 1). Then we exclude the US (Model 2) because it has adopted neither IFRS nor ISA. Because we are using panel data, it is important to decide between using the fixed effects or random effects model (Tauringana and Chithambo 2016). We have used both the fixed effects and random effects estimators to choose the most appropriate model. We performed the Hausman test, which did not accept the null hypothesis that unobservable heterogeneity is uncorrelated with the regressors. This implies a significant difference between random effects and fixed effects. This provides a statistical reason to argue that fixed effects is more efficient and effective for this study (Models 3 and 4). We also grouped the countries into developed and developing to provide more insights on the determinants of ARQ (Models 5 and 6). Our argument is that the level of significance of the variables may vary.

The analytical method used to test the hypotheses involves the estimation of the following general form equations for a balanced panel data set of 26 countries over a nine-year period ( 234 observations):

$$
\begin{aligned}
& A R Q=\beta_{0}+\beta_{1} I F R S+\beta_{2} I S A+\beta_{3} P O L Y S+\beta_{4} \sum \text { Control Variables }+\varepsilon \text { (1) } \\
& A R Q_{-U S}=\beta_{0}+\beta_{1} I F R S+\beta_{2} I S A+\beta_{3} P O L Y S+\beta_{4} \sum \text { Control Variables }+\varepsilon \text { (2) } \\
& A R Q=\beta_{0}+\beta_{1} I F R S+\beta_{2} I S A+\beta_{3} P O L Y S+\beta_{4} \sum \text { Control Variables }+ \text { COUNTRY FIXED EFFECTS } \\
& (3) \\
& A R Q=\beta_{0}+\beta_{1} I F R S+\beta_{2} I S A+\beta_{3} P O L Y S+\beta_{4} \sum \text { Control Variables }+\varepsilon+Y E A R \text { FIXED EFFECTS } \\
& (4) \\
& A R Q_{\text {developed }}=\beta_{0}+\beta_{1} I F R S+\beta_{2} I S A+\beta_{3} P O L Y S+\beta_{4} \sum \text { Control Variables }+\varepsilon \text { (5) } \\
& A R Q_{\text {developing }}=\beta_{0}+\beta_{1} I F R S+\beta_{2} I S A+\beta_{3} P O L Y S+\beta_{4} \sum \text { Control Variables }+\varepsilon \text { (6) }
\end{aligned}
$$

Dependent variable

$A R Q$ as the dependent variable is the perceived quality of auditing and reporting in country $i$ at time $t$ measured on a seven-point Likert-type scale where $1=$ lowest perceived quality, ..., $7=$ highest perceived quality.

Standards Board (IAASB); and (4) Other (i.e., a country for which no data are available or that has declared convergence with ISAs but is far from achieving this objective).

${ }^{5}$ (1) IFRSs required for all; (2) IFRSs required for some; (3) IFRSs permitted; and (4) IFRSs not permitted. 
$A R Q_{\text {-uS }}=$ the perceived quality of auditing and reporting excluding the US. We have run a different panel excluding the US in the sample because it has adopted neither IFRS nor ISA. The reason is to determine the impact on our results.

$A R Q_{\text {developed }}=$ the perceived quality of auditing and reporting of developed countries only.

$A R Q_{\text {developing }}=$ the perceived quality of auditing and reporting of developing countries only.

We have also grouped the countries into developed and developing because the levels of IFRS and ISA adoption, and the political systems are different. The reason for this is to determine whether the impact of the determinants is similar or not and if not why not.

\section{Independent variables}

The following independent variables are considered for this study:

IFRS = score of IFRS adoption and implementation measured in country $i$ at time $t$ measured on a scale of 1--4. $1=$ IFRS is not permitted, $2=$ IFRS is permitted, $3=$ IFRS is required for some and $4=$ IFRS is required for all. ISA = score of ISA adoption in country $i$ at time $t$ measured on a scale of 1--4. $1=$ ISAa not adopted, 2 = country claims national standards are ISAs, $3=$ standard setters recommend ISAs and $4=$ ISAs are mandatory by law. POLYS = political system measured as a democracy index scaled 0--10 by the Economic Intelligence Unit. Year dummy = dummy variable equal to one if the country is in the year $i$ and zero otherwise.

Using equation (1) we run a pooled regression to assess the impact of the determinants on ARQ using all 26 countries over a period of nine years. We subsequently remove the US data and re-run the regression using equation (2) to determine if the coefficients of the determinants of ARQ change for the remaining 25 countries. Since the basis of ISA adoption varies among countries, country dummy variables are included in the model to capture differences in ISA adoption in different countries. This is presented in equation (3). In order to provide additional controls for other omitted variables that could affect ISA adoption, we include year-specific dummy variables to control for systematic time period effects. This is presented in equation (4). We further divide the sample of countries into developed and developing (equations 5 and 6) using the World Economic Situation and Prospects Country Classification (2014) and investigate if the determinants of ARQ differ both in type and magnitude. At this level the year and country fixed effects are also tested. The dummies for year and country are not reported in the tables for terseness.

\section{Control variables}

Based on past studies we have identified the following control variables and they are explained below.

\section{Legal system(s) and $A R Q$}

The legal tradition of a country influences its auditing and reporting systems and practices (David and Brierly 1985; Salter and Doupnik 1992; Nobes 1983, 1998; Francis et al. 2003; Boolaky 2004; Nobes and Parker 2008). Nobes (1998) uses legal traditions to classify the accounting of countries (see also Salter and Doupnik 1992). La Porta et al. (1998) suggest that common law tradition provides more investor protection including minority investor protection and relate it to the extent of disclosure requirements (see also La Porta 2006). Many studies, such as La Porta et al. (2000) and Chen et al. (2010), use La Porta et al.'s $(1997,1998)$ indices to measure the impact of the legal system on the quality of reporting. However, Boolaky and Cooper (2015) use the WEF GCR dataset and suggest that judicial independence and efficiency of the legal framework impact on accounting quality. Controlling for these two legal variables we investigate how IFRS, ISA and political systems influence ARQ in the AsiaPacific region. We use the country scores for judicial independence and the efficiency of the legal framework as published by the WEF. 
Securities exchange regulations (SER) seek to mandate firms to be transparent both during good and bad years and as a result mitigate information asymmetry and increase secondary markets' liquidity (Hope 2003; Bushee and Leuz 2005; Houque et al. 2012). They also mandate listed companies to produce a high standard of auditing and reporting and the penalties for noncompliance can be significant both from an enforcement and market reaction perspective (Soderstrom and Sun 2007; also see Hail and Leuz 2006). As our next control variable, we use a general score relating to the perception of securities exchange regulations published by the WEF.

\section{Corporate governance quality and $A R Q$}

The quality of corporate governance influences the quality of auditing and reporting (Levitt 1998, 2000; Francis et al. 2003; Cohen et al. 2004; García-Meca and Sánchez-Ballesta 2009). For example, Levitt (1998) suggests that by enhancing corporate governance, the strength of auditing and reporting will improve. Francis et al. (2003) contend that the quality of corporate governance positively affects the quality of reporting. This argument is also supported by De Zoort et al. (2003). In our paper two elements are considered to be critical in determining the quality of corporate governance at firm level in a country. They are: 1) efficacy of the corporate board; and 2) reliance on professional management. Boolaky (2012) and more recently, Boolaky and Cooper (2015), investigated the impact of these two variables on the strength of auditing and reporting in the European region. Both studies find support for the relevance of the efficacy of the corporate board but not for the reliance on professional management in the case of Asia. We therefore include both as control variables. Efficacy of board and reliance on professional management are drawn from the scores published by the WEF.

\section{Prevalence of foreign ownership and $A R Q$}

A review of cross-national studies of corporate accounting quality (e.g., García-Meca and Sánchez-Ballesta 2009; Houqe et al. 2012; Ahmed et al. 2013a) shows that the extent of foreign ownership (e.g., whether at investment, associate or subsidiary levels) is not usually included as a variable of interest whilst it is plausible that foreign shareholding may influence the adoption of particular accounting policies. On the other hand, Boolaky and Cooper (2015) argue that the prevalence of foreign ownership in national as well as multinational units in a given country does influence the perceptions of accounting and reporting quality. In effect, the prevalence of foreign ownership indicates a greater integration with the global marketplace and may lead to mimetic behaviours to achieve greater legitimacy and access to resources (Judge et al. 2010: 164). We therefore conjecture the prevalence of foreign ownership as our last control variable in this study.

\section{Findings and Discussion}

\section{Descriptive statistics}

We report the country classification by IFRS and ISA in 2007, 2011 and 2015 in Table 1. Columns 2--4 report on IFRS adoption whereas columns 5--7 refer to ISA. Five countries (Bangladesh, Cambodia, Chile, China and Russia) moved from category D (IFRS not permitted) to category A (IFRS required for all) in 2015. Six other countries moved from category C (IFRS permitted) to category A (IFRS required for all). Four countries (US, Vietnam, Singapore and Philippines) still remain in category D (IFRS not permitted). Madagascar, a French-speaking country that traditionally relies on the French Accounting Plan 2005, has moved from category C (IFRS permitted) to category B (IFRS required for some). Mauritius is among the few countries that has adopted IFRS and made it mandatory in its Companies Act in 2001. With regard to ISA adoption, 11 countries are in category C, that is, national standards are ISAs subject to modifications. For example, the Australian Standards on Auditing 230 has additiona requirements to ISA 230. There are eight countries falling under category D. These countries declared convergence with ISAs but IFAC does not put forward any evidence in this regard. Mauritius is in category A, that is, ISA is required by law.

Table 2 presents the country-level ARQ scores. For the sake of brevity, we only discuss a few of the scores. New Zealand and the US have the highest scores (6.3) followed by Singapore, Australia and Canada with 6.2 respectively. Among these five countries, Australia and New Zealand are in category A for IFRS and in categories C and B for ISA respectively. Singapore and the US do not use IFRS per se although in the latter case national auditing standards are ISAs subject to modification (as in Australia). Two countries score the minimum (3.8), namely Bangladesh and Vietnam. Bangladesh adopted IFRS in 2015 and the national 
standard setter adopted ISAs in 2011. The mean ARQ score of Russia over this nine-year period is 3.833 with a maximum of four. This can be related to the late adoption of IFRS which was to be effective in $2012^{6}$ and it is noted that ISA adoption is purely voluntary. India and Indonesia also have a high mean ARQ score (5.122 and 4.589 respectively). In 2007 neither country was using IFRS but did so in 2015. Indonesia required IFRS for entities whereas India ${ }^{7}$ only permitted the use of IFRS.

Comment [SH11]: Typesetter: insert Table 2 near here

We report the descriptive statistics for both the dependent and independent variables in Table 2.1. The mean ARQ is 4.820 with a standard deviation of (0.8442). The Asia-Pacific's perceived ARQ score is close to the average score of five published by the WEF. The mean value of IFRS adoption scaled by category is 2.448 , which suggests that overall IFRSs are at least permitted in the majority of the countries within the region, except for a few countries such as the US, Singapore and Vietnam. The mean value of ISA adoption (1.72) indicates that in some of these countries ISAs are either adopted with modifications or there is little evidence to determine their actual level of convergence. The mean value of political system (6.150) indicates that only a few of these countries have full democracy in place. The other variables (efficacy of corporate board, reliance on professional management, efficiency of legal framework, securities exchange regulations, protection of minority interests, prevalence of foreign ownership) are all measured on a scale of 1--7 and the mean values are above 3.5. Appendix D reports the ARQ for the nine years between 2007 and 2015 to supplement Table 2.1.

\section{Pearson correlations}

Table 3 presents the Pearson correlations for the dependent and independent variables used in the regression analysis and Table 3.1 the multi-collinearity test. We have considered a number of country variables which could affect ARQ but due to the multicollinearity problem we had to remove them from our analysis. Correlations greater than 0.9 between the independent variables can signal the presence of multicollinearity, which might influence the findings in the regression analysis (Field 2000; Hair et al. 2006). Table 3.1 confirms that there is no significant impact of multicollinearity on the model. Neither the tolerance factor nor the VIF values are a matter for concern. Overall the findings from Tables 3 and 3.1 provide support for the relationships put forward in our hypotheses.

\section{Regression results}

Table 4 reports the regression results in Models 1 and 2. Model 1 is a pooled regression including all 26 countries whereas Model 2 excludes the US. Both models suggest that two of the three independent variables are significant determinants of ARQ. The $\mathrm{AR}^{2}$ for Model 1 is 0.892 , which indicates that the overall model fit is $89.2 \%$. This implies that both the adoption of IFRS and ISA significantly influences ARQ. The adoption of IFRS is positively associated with ARQ (beta $=.089, t=3.432, \mathrm{p}=.001$ ) which therefore supports Hypothesis 1 . This finding is consistent with the expectations put forward by Soderstrom and Sun (2007) and Ding et al. (2007) who suggest that IFRS regulation enhances the credibility of accounting information. Our results are also more categorical in nature compared to the evidence put forward by Houqe et al. (2012), who found IFRS adoption to be beneficial for accounting quality in countries with strong protection regimes, and by Ahmed et al. (2013a, 2013b), who respectively emphasise the minimal and partial benefits of IFRS adoption on value relevance and other accounting quality metrics. At the same time, our result does not support the comments by: (1) Schipper (2005) who contends that implementing a single standard in different companies and countries is problematic, thus reducing its positive impact on the perceived quality of accounting outputs; and (2) Abongwa (2005) who contends that the convergence between the FASB and the IASB has not been achieved because of

${ }^{6}$ Russia's Federal Law (No. 208-FZ) on 'Consolidated Financial Statements' of 27 July 2010 required that, from 2012 onwards, the so-called 'public interest entities', including listed companies, prepare their accounts in accordance with IFRS as opposed to the national accounting standards.

${ }^{7}$ In March 2014, the Institute of Chartered Accountants of India (ICAI) submitted to the Ministry of Corporate Affairs a proposed new IFRS roadmap and convergence plan for India. In the proposed roadmap, the ICAI recommended implementation of IND-AS by selected companies only in the preparation of their consolidated financial statements. 
environmental and cultural differences and that the perceptions of accounting quality will not necessarily become more aligned cross-nationally merely because there appears to be greater convergence of accounting standards between countries.

The adoption of ISA is also found to be positively but only moderately associated with ARQ (beta $=.046, t=1.693, p=$ .092), thus partly supporting Hypothesis 2. This indicates that the use of ISAs or its equivalent in the Asia-Pacific region has influenced perceptions of accounting quality. Between 2007 and 2011, the number of countries whose standard setters adopted ISAs increased from one to 10, whereas 12 other countries in 2015 mandated that their national auditing standards should be based on ISAs subject to modifications. So, whilst the diversity in the levels of ISA adoption is similar to the case of IFRS in the AsiaPacific region, mimetic pressures towards convergence of auditing standards are observed to be positively related to perceptions of national accounting quality. One possible explanation for this result is that the adoption of ISAs has a legitimating value and conveys assurances as to the basis upon which financial accounting information is prepared (under IFRS) and audited. Given the paucity of empirical research on the impact of ISAs (e.g., Christensen et al. 2014), this finding contributes to the literature by showing how ISAs influence ARQ in the presence of an IFRS adoption variable and brings some empirical support to the insights put forward by Simunic et al. (2014).

As far as the political system is concerned, the model suggests that POLYS is positively but not significantly associated with ARQ (beta $=.045, t=1.443, p=.150$ ). This implies that auditing and reporting quality is not materially influenced by the level of democracy in a country. A possible reason for this finding is that many of these countries are classified as flawed democracies or hybrid ones, and hence ARQ may not be as high as in the few fully democratic countries such as Australia, Canada, the US and New Zealand.

When excluding the US from the pool of countries, Model 2 reports an $\mathrm{AR}^{2}$ of 0.90 or $90 \%$. The impact of the three variables of interest does not significantly change. However, there are changes to the impact of two of the six control variables. Without the US, the impact of the efficacy of corporate board loses significance, moving away from a significant positive (beta $=$ $.098, t=2.451, p=.015$ ) to a non-significant positive relationship (beta $=.034, t=.858, p=.392$ ). The same effect is reported to the control variable prevalence of foreign ownership (POFO).

Most of the variables are reported to be positively related to ARQ even when we control for year fixed effects and country fixed effects (see Table 5, Models 3 and 4). However, the prevalence of foreign ownership, although remaining positively related to ARQ, loses significance when we control for year fixed effects. In results not reported here, in the years 2008--2015, calendar-year fixed effects are not significant but positively related to ARQ. We also control for the effects of the global financial crisis but the result remains unchanged. When we control for country fixed effects the significance increases from .05 to .01 and that could also be explained as a result of the attractive investment climate offered by countries like Bangladesh, the Philippines, Vietnam and Peru. For example, in 2015, the Government of Vietnam abolished limits on foreign ownership in many listed companies

We further segmented the countries into developed and developing in order to determine if there are material changes in the determinants of ARQ between the two groups. We report the results in Table 6, Models 5 and 6. Our results report some changes. The efficacy of the legal framework is found to be a positively significant driver of ARQ in developed countries whereas in developing countries it is positive but not significant. The same applies to the efficacy of the corporate board. As discussed earlier, the board of directors appears less able to influence perceptions of ARQ in developing countries as opposed to developed countries. IFRS and ISA adoption remain positively related to ARQ in both groups, except for the case of ISA adoption, where the level of significance is higher $(p<.05)$ in the sample of developed nations compared to the developing ones $(p>.05$ but $<.10)$. This suggests that the impact of ISA on ARQ is less rigorous or at the very least only beginning to emerge in developing countries.

\section{Conclusion and Implications}

The WEF publishes a country-level ARQ score each year. The score conveys a metric of ARQ from a user's perspective, rather than from an accountant's perspective, and is of relevance to investors, standard setters, professional practitioners and other users. Using data from 26 countries from 2007 to 2015 in the Asia-Pacific, we find support for the neo-institutional perspective in underpinning the determinants of the differences and similarities cross-nationally. 
We provide empirical evidence for the three institutional pressures (coercive, mimetic and normative) as measured by the efficacy of the board, securities exchange regulations, laws related to the protection of minority interests, prevalence of foreign ownership, IFRS and ISA adoption as well as the political system on ARQ perceptions at a country level. In support of the extant literature, IFRS is reported as having a significant impact on ARQ, which implies that in countries where IFRS is adopted and used, it will have a significant effect on perceived accounting quality relative to other non-IFRS accounting regimes, for example, local GAAP. Moreover, the efficiency of the legal framework, which plays a key role in the legal machinery of a country, does not significantly influence ARQ. One reason could be because in some of these countries the possibility of challenging a court dispute is perceived to be low. However, when developed nations are looked at separately, the efficiency of the legal framework is a positively significant determinant of ARQ. With regards to mimetic pressure(s), that is, the prevalence of foreign ownership, our finding supports the institutional prediction when considering the whole sample, that is, a higher level of foreign involvement is associated with higher perceptions of ARQ. Finally, whilst almost all countries around the globe appear to be converging, if not transitioning, towards IFRS and ISA and auditors and preparers of accounts are expected to comply with international standards, our findings suggest that perceived ARQ is more associated with IFRS than ISA adoption. Lastly, the political system was not found to be a significant determinant of ARQ.

Our findings are wider in scope because we rely on actual country-level data to explain the determinants of accounting quality. The most recent studies using such data and ARQ are that of Boolaky and O'Leary (2011), Boolaky (2012) and Boolaky and Cooper (2015), but they do not explicitly rely on any theory as we have done in the present study, whilst drawing upon more recent data. Consequently, this paper contributes to the literature on cross-national studies of accounting quality (Leuz et al. 2003; Houque et al. 2012) by considering a different dimension and measurement of quality drawn from a user's perspective, as opposed to one that is devised from a preparer's perspective. Informed by concepts from the neo-institutional perspective, our results emphasise the significantly positive role of key institutional factors, IFRS and ISA to a somewhat lesser extent.

In terms of limitations, it has to be acknowledged that the measurement and concept of accounting quality used in this study is based on questionnaire data that were not collected primarily for this research. Secondary data of this nature can at best only provide a snapshot of national attitudes towards accounting information and could be influenced by factors that are not necessarily or directly related to the preparation or use of accounting information in the various countries. Yet, the survey has been in operation for a number of years and has been based on a fairly rigorous method of data collection and weighing. Second, the institutional perspective has focused on a number of coercive-, mimetic- and normative-led variables but it is plausible that other variables have not been included in the model. Nonetheless, the limited data set has precluded the reliance on a large number of independent variables and the study has instead focused on the more salient ones that may matter within the Asia-Pacific region.

\section{References}

$<B \mid B L>$

Abongwa, A.I. 2005, An Empirical Investigation of the Relationships Between Culture and Accountants Attitude Towards the Harmonisation of International Accounting Standards in the United States of America and Cameroon, PhD Thesis, Nova Southeast University.

Ahmed, K., Keryn C. and Hichem K. 2013a, ‘A Meta-analysis of IFRS Adoption Effects’, The International Journal of Accounting, 48 (2): 173--217.

Ahmed, A.S., Neel, M. and Wang, D. 2013b, 'Does Mandatory Adoption of IFRS Improve Accounting Quality? Preliminary Evidence', Contemporary Accounting Research, 30 (4): 1344--72.

Al-Awaqleh, Q.A. 2010, 'Factors That Influence the Adoption of International Standards on Auditing in Jordan', International Management Review, 6 (2): 28--34. 
Baboukardos, D. and Rimmel, G. 2014, 'Goodwill Under IFRS: Relevance and Disclosures in an Unfavorable Environment', Accounting Forum, 38 (1): 1-17.

Bajra, U. and Cadez, S. 2017, 'The Impact of Corporate Governance Quality on Earnings Management: Evidence from European Companies Cross Listed in the US', Australian Accounting Review. Available at: http://onlinelibrary.wiley.com/doi/10.1111/auar.12176/full, accessed 27 December 2017

Ball, R., Kothari, S.P. and Robin, A. 2000, 'The Effect of International Institutional Factors on Properties of Accounting Earnings', Journal of Accounting and Economics, 29 (1): 1-51.

Ball, R., Robin, A. and Wu, J.S. 2003, 'Incentives Versus Standards: Properties of Accounting Income in Four East Asian Countries', Journal of Accounting and Economics, 36 (1--3): 235--70.

Barbue, E. 2004, 'L'Harmonisation Comptable Internationale: D'un Vagabondage Comptable à l'Autre', Comptabilité Contrôle Audit, 10 (1): 37--61.

Barth, M., Clinch, G. and Shibano, T. 1999, 'International Accounting Harmonization and Global Equity Markets', Journal of Accounting and Economics, 26 (13): 201-35.

Barth, M., Landsman, W. and Lang, M. 2006, 'International Accounting Standards and Accounting Quality', Working Paper, Stanford University and University of North Carolina at Chapel Hill.

Beckert, J. 2010, 'Institutional Isomorphism Revisited: Convergence and Divergence in Institutional Change', Sociological Theory, 28 (2): 150--66.

Belkaoui, A. 1983, 'Economic, Political, and Civil Indicators and Reporting and Disclosure Adequacy: Empirical Investigation', Journal of Accounting and Public Policy, 2 (3): 207--19.

Black, E.L. and Carnes, T.A. 2006, 'Analyst's Forecasts in Asian-Pacific Markets: The Relationship Among Macroeconomic Factors, Accounting Systems, Bias and Accuracy', Journal of International Financial Management and Accounting, 17 (3): 209--27.

Boolaky, P.K. 2004, 'Accounting Developments in Africa: A Study of the Impact of Colonisation and Legal Systems on Accounting Standards in Sub-Saharan Africa', Delhi Business Review, 5 (1): 123--31.

Boolaky, P.K. 2012, 'Auditing and Reporting in Europe: An Analysis Using Country Level Data', Managerial Auditing Journal, 27 (1): 41--65. 
Boolaky, P.K. and Cooper, B.J. 2015, 'Comparing the Strength of Auditing and Reporting Standards and Investigating Their Predictors in Europe and Asia’, Australian Accounting Review, 25 (3): 292--308.

Boolaky, P.K. and O'Leary, C. 2011, 'Determining the Strength of Auditing Standards and Reporting', Corporate Ownership \& Control, 8 (4): 291--304.

Bradbury, M.E. and Mear, K.M. 2017, 'Interpreting the Impact of IFRS Adoption', Australian Accounting Review. Available at:

\section{7.}

Brody, R.G., Moscove, S. and Wnek, R. 2005, 'Auditing Standards in Poland: Past, Present and Future', Managerial Auditing Journal, 20 (1): 36--46.

Bushee, B. and Leuz, C. 2005, 'Economic Consequences of SEC Disclosure Regulation: Evidence from the OTC Bulletin Board', Journal of Accounting \& Economics, 39 (2): 233--64.

Chen, H., Tang, Q., Jiang, Y. and Lin, Z. 2010, 'The Role of International Financial Reporting Standards in Accounting Quality: Evidence from the European Union', Journal of International Financial Management \& Accounting, 21 (3): 1--57.

Cheong, C.S., Kim. S. and Zurbruegg, R. 2010, 'The Impact of IFRS on Financial Analysts' Forecast Accuracy in the Asia-Pacific Region', Pacific Accounting Review, 22 (2): 124--46.

Christensen, B.E., Glover, S.M. and Wolfe, C.J. 2014, 'Do Critical Audit Matter Paragraphs in the Audit Report Change Nonprofessional Investors' Decision to Invest?', Auditing: A Journal of Practice \& Theory, 33 (4): 71--93.

Chua, W.F. and Taylor, S.L. 2008, 'The Rise and Rise of IFRS: An Examination of IFRS Diffusion', Journal of Accounting and Public Policy, 27 (6): 462--73.

Cohen J., Khrisnamoorthi, G. and Arnie, W. 2004, 'The Corporate Governance Mosaic and Financial Reporting Quality', Journal of Accounting Literature, 23: 87--152.

Cornelius, P. 2005, 'Governance: Good Corporate Practices in Poor Corporate Governance Systems', Corporate Governance, 5 (3): 12--23.

David, R. and Brierly, J. 1985, Major Legal Systems in the World Today, Stevens and Sons, London. 
Dechow, P. and Dichev, I. 2002, 'The Quality of Accruals and Earnings: The Role of Accrual Estimation Errors', The Accounting Review, 77 (Supplement): 35-59.

Dellaportas, S., Senarath-Yapa, P.W. and Sivanantham, S. 2008, 'Internationalising Auditing Standards: Stakeholder Views on Australia’s Strategic Directions', Managerial Auditing Journal, 23 (7): 663 --84

Deloitte 2008, Use of IFRS for Reporting by Domestic Listed Companies by Country and Region. Available at: http://www.iasplus.com/country/useias.htm, accessed 10 December 2012.

Deloitte 2010, 'Use of IFRS by Jurisdictions: Domestic Listed and Unlisted Companies', IAS Plus, 1--6.

De Zoort, F.S., Hermanson, D.L. and Houston, R.D. 2003, 'Audit Committee Support for Proposed Audit Adjustments: A Source Credibility Perspective', Auditing: A Journal of Practice and Theory, 22 (2): 189-205.

DiMaggio, P. and Powell, W.W. 1983, 'The Iron Cage Revisited: Institutional Isomorphism and Collective Rationality in Organizational Fields', American Sociological Review, 48 (2): 147-60.

Ding, Y., Hope, O., Jenajean, T. and Stolowy, H. 2007, 'Differences Between Domestic Accounting Standards and IAS: Measurement, Determinants, and Implications', Journal of Accounting and Public Policy, 26: $1--38$

Field, A. 2000, Discovering Statistics Using SPSS for Windows, Sage Publications, Thousand Oaks, CA.

Francis, J.R., Khurana, I.K. and Pereira, R. 2003, 'The Role of Accounting and Auditing in Corporate Governance and the Development of Financial Markets Around the World', Asia-Pacific Journal of Accounting and Economics, 10 (1): 1--30.

García-Meca, E. and Sánchez-Ballesta, J.P. 2009, 'Corporate Governance and Earnings Management: A Meta-analysis', Corporate Governance: An International Review, 17 (5): 594--610.

Hail, L. and Leuz, C. 2006, International Differences in the Cost of Equity Capital: Do Legal Institutions and Securities Regulation Matter?', Journal of Accounting Research, 44 (5): 485--530.

Hair Jr., J.F., Black, W.C., Babin, B.J., Anderson, R. and Tathum, R. 2006, Multivariate Data Analysis (6th edition), Prentice Hall, Upper Saddle River NJ. 
Hassabelnaby, H.R., Epps, R.W. and Said, A.A. 2003, 'The Impact of Environmental Factors on Accounting Development: An Egyptian Longitudinal Study', Critical Perspectives on Accounting, 14 (3): 273--92.

Hegarty, J.F., and Barros, A., 2004. Implementation of International Accounting and Auditing Standards: Lessons from the World Bank's Accounting and Auditing ROSC Program, World Bank Publication..

Hoang, T.C., Abeysekera, I. and Ma, S. 2017, 'The Effect of Board Diversity on Earnings Quality: An Empirical Study of Listed Firms in Vietnam', Australian Accounting Review, 27 (2): 146--63.

Hofstede, G. 1980, Cultural's Consequences: International Differences in Work Related Values, Sage, Beverly Hills, CA.

Hope, O.-K. 2003, 'Disclosure Practices, Enforcement of Accounting Standards, and Analysts Forecasts Accuracy: An International Study', Journal of Accounting Research, 41 (2): 235-72.

Houqe, M.N., Van Zijl, T., Dunstan, K. and Karim, A.K.M.W. 2012, 'The Effect of IFRS Adoption and Investor Protection on Earnings Quality Around the World', International Journal of Accounting, 47 (3): 333-55 .

Hribar, P., Kravett, T. and Wilson, R. 2010, ,A New Measure of Accounting Quality', Working Paper. Available at SSRN: http://ssrn.com/abstract $=$ 1283946, accessed 27 December 2017.

Humphrey, C. and Loft, A. 2013, 'Contemporary Audit Regulation: Going Global!', in G. Caprio Jr. (ed.), Handbook of Key Global Financial Markets, Institutions, and Infrastructure, Vol. 31, Elsevier, Boston: 333-43.

International Federation of Accountants (IFAC) 2014, A Framework for Audit Quality. Available at: https://www.ifac.org/publications-resources/framework-audit-quality-key-elements-create-environment-audit-

quality, accessed 19 May 2017.

International Federation of Accountants (IFAC) 2015, Basis of ISA Adoption by Jurisdiction. Available at: www.ifac.org, accessed 17 May 2017.

Comment [SH18]: Author: not cited in text

Judge, W., Li, S. and Pinsker, R. 2010, 'National Adoption of International Accounting Standards: An Institutional Perspective', Corporate Governance: An International Review, 18 (3): 61--174. 
Kabir, H. and Laswad, F. 2015, 'The Impact of Improvements in Institutional Oversight on IFRS Accrual Quality in Europe', Australian Accounting Review, 25 (4): 428--44.

Kabir, M.H., Laswad, F. and Islam, M.A. 2010, 'Accounts and Earnings Quality', Australian Accounting Review, 20 (4): 343--57.

La Porta R. 2006, 'What Works in Securities Law?', Journal of Finance, 61 (1): 1--32.

La Porta, R., Lopez-de-Silanes, A., Shleifer, A. and Vishny, R. 1997, 'Legal Determinants of External Finance', Journal of Finance, 2 (3): 1113--51.

La Porta, R., Lopez-de-Silanes, A., Shleifer, A. and Vishny, R. 1998, 'Legal Determinants of External Finance', The Journal of Political Economy, 106 (6): 1113--55.

La Porta, R., Lopez-de-Silanes, A., Shleifer, A. and Vishny, R. 2000, 'Investor Protection and Corporate Governance', Journal of Financial Economics, 58 (1--2): 3--27.

Larson, R.K. and Kenny, S.Y. 1995, ‘An Empirical Analysis of International Accounting Standards, Equity Markets, and Economic Growth in Developing Countries', Journal of International Financial Management and Accounting, 6 (2): 130--57.

Leuz, C. 2010, 'Different Approaches to Corporate Reporting Regulation: How Jurisdictions

Differ and Why', Accounting and Business Research, 40 (3): 229--56.

Leuz, C., Nanda, D. and Wyscoki, P.D. 2003, 'Earnings Management and Investor Protection: An International Comparison', Journal of Financial Economics, 69 (3): 505--27.

Levitt, A. 1998, The Numbers Game. Available at: http:/www.rutger.edu/accounting/raw/aa/newsarc/pr, accessed 19 May 2017.

Levitt, A. 2000 Renewing the Covenant with Investors, Speech at New York University Center for Law and Business. Available at http:/www.sec.gov/news/speeches/spch370.htm, accessed 19 May 2017.

Lont, D. and Wong, N. 2010, 'Issues in Financial Accounting and Reporting: A Pacific Rim Focus', Pacific Accounting Review, 2 (2): 85--91.

McNichols, M. 2002, 'Discussion of the Quality of Accruals and Earnings: The Role of Accrual Estimation Errors', The Accounting Review, 77 (Supplement): 61--69. 
Mennicken, A. 2008, 'Connecting Worlds: The Translation of International Auditing Standards into PostSoviet Audit Practice', Accounting, Organizations and Society, 33 (4--5): 384--414.

Nobes, C.H. 1983, 'A Judgemental International Classification of Financial Reporting Practices', Journal of Business Finance and Accounting, 10 (1): 11--19.

Nobes, C.H. 1998, 'Towards a General Model of the Reasons for International Differences in Financial Reporting', Abacus, 36 (2): 162--87.

Nobes, C.H. 2010, 'On Researching into the Use of IFRS by Private Entities in Europe', Accounting in Europe, 7 (2): 213--26.

Nobes, C. and Parker, R. 2008, Comparative International Accounting, $10^{\text {th }}$ edition, Pearson Education, UK.

Rahman, A., Yammeesri, J. and Perera, H. 2010, 'Financial Reporting Quality in International Settings: A Comparative Study of the USA, Japan, Thailand, France and Germany', International Journal of Accounting, $45(1): 1--34$.

Salter, S.B. and Doupnik, T.S. 1992, 'The Relationship Between Legal Systems and Accounting Practices', Advances in International Accounting, 5 (1): 3--22.

Scapens, R. 1994, 'Never Mind the Gap: Towards an Institutional Perspective on Management Accounting Practices', Management Accounting Research, 5 (3--4): 301--21.

Schipper, K. 2005, 'The Introduction of International Accounting Standards in Europe: Implications for International Convergence', European Accounting Review, 14 (1): 101--26.

Schockaert, D. and Houyous, N. 2007, 'International Standards on Auditing within the European Union', Forum Financier/Revue Bancaire et Financier, 72 (8): 515--29.

Scott, W.R. 2001, Institutions and Organizations, 2nd edition, Sage, Thousand Oaks, CA.

Shleifer, A. and Vishny, R. 1997, ‘A Survey of Corporate Governance’, The Journal of Finance 52 (2): 737-83.

Simunic, D.A., Ye, M. and Zhang, P. 2014, 'Improving Audit Value with Country Specific Interpretations After International Auditing Standards Are Adopted', Rotman School of Management Working Paper (2402447). 
Soderstrom, N.S. and Sun, K.J. 2007, ,IFRS Adoption and Accounting Quality: A Review', European Accounting Review, 16 (4): 675--702.

Spamann, H. 2010, 'The Anti-directors' Rights Index Revisited', Review of Financial Studies, 23 (2): $467--$ 86.

Stangor, C. 2006, Research Methods for Behavioural Sciences, $3^{\text {rd }}$ edition, Houghton Mifflin, Boston.

Tauringana, V. and Chithambo, L. 2016, 'Determinants of Risk Disclosure Compliance in Malawi: A Mixedmethod Approach', Journal of Accounting in Emerging Economies, 6 (2): 111--37.

World Bank 2002--2015, World Bank Report on Observance of Standards and Codes. Available at: www.wordlbank.org/ifa/rocs_aa.html, accessed 14 May 2017.

World Economic Forum 2007--2015, Global Competitiveness Reports. Available at:

https://www.weforum.org/reports/the-global-competitiveness-report-2016-2017-1, accessed 14 May 2017.

$</ B \mid B L>$

Table 1 Country classification by use of IFRS adoption of ISA

\begin{tabular}{|l|c|c|c|c|c|c|}
\hline \multicolumn{1}{|c|}{ Country } & $\mathbf{2 0 0 7}$ & $\mathbf{2 0 1 1}$ & $\mathbf{2 0 1 5}$ & $\mathbf{2 0 0 7}$ & $\mathbf{2 0 1 1}$ & $\mathbf{2 0 1 5}$ \\
\hline Australia & $\mathrm{A}$ & $\mathrm{A}$ & $\mathrm{A}$ & $\mathrm{C}$ & $\mathrm{C}$ & $\mathrm{C}$ \\
\hline Bangladesh & $\mathrm{D}$ & $\mathrm{D}$ & $\mathrm{A}$ & $\mathrm{A}$ & $\mathrm{B}$ & $\mathrm{C}$ \\
\hline Brunei & $\mathrm{D}$ & $\mathrm{D}$ & $\mathrm{C}$ & $\mathrm{D}$ & $\mathrm{D}$ & $\mathrm{D}$ \\
\hline Cambodia & $\mathrm{C}$ & $\mathrm{C}$ & $\mathrm{A}$ & $\mathrm{D}$ & $\mathrm{D}$ & $\mathrm{D}$ \\
\hline Canada & $\mathrm{D}$ & $\mathrm{A}$ & $\mathrm{B}$ & $\mathrm{B}$ & $\mathrm{C}$ & $\mathrm{C}$ \\
\hline Chile & $\mathrm{D}$ & $\mathrm{A}$ & $\mathrm{A}$ & $\mathrm{C}$ & $\mathrm{C}$ & $\mathrm{B}$ \\
\hline China & $\mathrm{C}$ & $\mathrm{A}$ & $\mathrm{A}$ & $\mathrm{C}$ & $\mathrm{C}$ & $\mathrm{B}$ \\
\hline India & $\mathrm{D}$ & $\mathrm{D}$ & $\mathrm{C}$ & $\mathrm{C}$ & $\mathrm{B}$ & $\mathrm{C}$ \\
\hline Indonesia & $\mathrm{D}$ & $\mathrm{D}$ & $\mathrm{B}$ & $\mathrm{D}$ & $\mathrm{D}$ & $\mathrm{D}$ \\
\hline Japan & $\mathrm{D}$ & $\mathrm{C}$ & $\mathrm{C}$ & $\mathrm{D}$ & $\mathrm{B}$ & $\mathrm{C}$ \\
\hline Korea & $\mathrm{D}$ & $\mathrm{A}$ & $\mathrm{A}$ & $\mathrm{C}$ & $\mathrm{B}$ & $\mathrm{C}$ \\
\hline Madagascar & $\mathrm{C}$ & $\mathrm{B}$ & $\mathrm{B}$ & $\mathrm{D}$ & $\mathrm{D}$ & $\mathrm{D}$ \\
\hline Malaysia & $\mathrm{D}$ & $\mathrm{D}$ & $\mathrm{A}$ & $\mathrm{C}$ & $\mathrm{B}$ & $\mathrm{C}$ \\
\hline Mauritius & $\mathrm{A}$ & $\mathrm{A}$ & $\mathrm{A}$ & $\mathrm{A}$ & $\mathrm{A}$ & $\mathrm{A}$ \\
\hline Mongolia & $\mathrm{C}$ & $\mathrm{A}$ & $\mathrm{A}$ & $\mathrm{D}$ & $\mathrm{B}$ & $\mathrm{B}$ \\
\hline Nepal & $\mathrm{C}$ & $\mathrm{A}$ & $\mathrm{A}$ & $\mathrm{D}$ & $\mathrm{C}$ & $\mathrm{C}$ \\
\hline New Zealand & $\mathrm{A}$ & $\mathrm{A}$ & $\mathrm{A}$ & $\mathrm{C}$ & $\mathrm{B}$ & $\mathrm{B}$ \\
\hline Pakistan & $\mathrm{D}$ & $\mathrm{D}$ & $\mathrm{B}$ & $\mathrm{C}$ & $\mathrm{B}$ & $\mathrm{C}$ \\
\hline Peru & $\mathrm{A}$ & $\mathrm{A}$ & $\mathrm{A}$ & $\mathrm{D}$ & $\mathrm{D}$ & $\mathrm{D}$ \\
\hline Philippines & $\mathrm{D}$ & $\mathrm{D}$ & $\mathrm{D}$ & $\mathrm{C}$ & $\mathrm{B}$ & $\mathrm{C}$ \\
\hline
\end{tabular}




\begin{tabular}{|l|c|c|c|c|c|c|}
\hline Russia & D & C & A & D & D & B \\
\hline Singapore & A & D & D & C & B & C \\
\hline Sri Lanka & C & C & A & D & C & D \\
\hline Thailand & C & A & A & C & C & C \\
\hline United States & D & C & D & D & D & D \\
\hline Vietnam & D & D & D & D & D & D \\
\hline
\end{tabular}

and IFAC website (https://www.ifac.org accessed several times).

Sources: Deloitte website (www.iasplus.com) and IFAC website (https://www.ifac
IFRS - A: IFRSs required for all; B: IFRSs required for some; C: IFRSs permitted;

D: IFRSs not permitted.

ISA - A: ISAs required by law; B: ISAs adopted by national standard setter;

C: National standards are ISAS subject to modification;

D: Others, i.e., no data available for these countries albeit that they 'declared' convergence with ISAs.

Table 2 Country-level audit and reporting quality score (2007--2015)

\begin{tabular}{|l|c|c|c|c|}
\hline \multicolumn{1}{|c|}{ Countries } & Mean & Max. & Min. & Std deviation \\
\hline Australia & 5.911 & 6.200 & 5.800 & 0.283 \\
\hline Bangladesh & 3.667 & 3.800 & 3.300 & 0.166 \\
\hline Brunei & 4.933 & 5.100 & 4.800 & 0.112 \\
\hline Cambodia & 3.800 & 3.900 & 3.500 & 0.122 \\
\hline Canada & 6.100 & 6.200 & 6.000 & 0.071 \\
\hline Chile & 5.400 & 5.600 & 5.000 & 0.300 \\
\hline China & 4.644 & 4.800 & 4.400 & 0.167 \\
\hline India & 5.122 & 5.600 & 4.900 & 0.254 \\
\hline Indonesia & 4.589 & 5.000 & 4.300 & 0.190 \\
\hline Japan & 5.356 & 5.500 & 5.100 & 0.133 \\
\hline Korea & 4.500 & 5.300 & 4.300 & 0.361 \\
\hline Madagascar & 3.489 & 3.900 & 3.200 & 0.298 \\
\hline Malaysia & 5.433 & 5.600 & 5.200 & 0.122 \\
\hline Mauritius & 5.533 & 5.600 & 5.500 & 0.050 \\
\hline Mongolia & 3.678 & 3.900 & 3.400 & 0.192 \\
\hline Nepal & 3.844 & 4.000 & 3.600 & 0.133 \\
\hline New Zealand & 6.189 & 6.300 & 6.100 & 0.060 \\
\hline Pakistan & 4.356 & 4.800 & 4.200 & 0.194 \\
\hline Peru & 4.900 & 5.100 & 4.700 & 0.141 \\
\hline Philippines & 4.933 & 5.200 & 4.600 & 0.250 \\
\hline Russia Federation & 3.833 & 4.000 & 3.700 & 0.100 \\
\hline Singapore & 6.167 & 6.200 & 6.100 & 0.050 \\
\hline Sri Lanka & 5.044 & 5.300 & 4.300 & 0.292 \\
\hline Thailand & 5.011 & 5.100 & 4.900 & 0.093 \\
\hline United States & 5.267 & 6.300 & 5.000 & 0.265 \\
\hline & & & & \\
\hline
\end{tabular}

${ }^{8}$ www.cpaaustralia.com.au;www.icab.org.bd; http://bdasc.org/faqs.php (Brunei); khcampus.wordpress.com(Cambodia) ICAC website; The Association of Accountants of Chile; 2006 for ISA, 2010 for clarified ISA http://www.ifac.org/news-events/201011/chinese-auditing-standards-board-and-international-auditing-and-assurance-standards; ICAI website (India) and others). These websites were accessed mainly on 6 February 2016 as from 10.12 am and re-accessed on 9 February as a counter-checking). The websites of the institute of accountants of all these countries were accessed. They not listed here for brevity. A copy of our detailed spreadsheet is available on demand. 
\begin{tabular}{|l|l|l|}
\hline Vietnam & 3.633 & 3.800 \\
\hline
\end{tabular}

3.400

0.173

ARQ score is measured on a Likert-type scale of 1--7.

Table 2.1 Descriptive statistics

\begin{tabular}{|l|l|l|l|l|}
\hline Variables & \multicolumn{1}{|c|}{ Mean } & \multicolumn{1}{|c|}{ Max. } & \multicolumn{1}{c|}{ Min. } & Std deviation \\
\hline ARQ & 4.820 & 6.300 & 3.200 & 0.844 \\
\hline Control variables \\
\hline EOCB & 4.724 & 5.900 & 0.900 & 0.621 \\
\hline ROPM & 4.741 & 6.300 & 3.100 & 0.818 \\
\hline EOLFW & 4.0149 & 6.300 & 2.500 & 0.922 \\
\hline SER & 4.386 & 6.000 & 2.200 & 0.933 \\
\hline PMIS & 4.454 & 6.000 & 2.600 & 0.755 \\
\hline POFO & 4.931 & 4.000 & 3.000 & 2.425 \\
\hline Variables of interest \\
\hline IFRS & 2.448 & 4.000 & 1.000 & 1.345 \\
\hline ISA & 1.722 & 4.000 & 0.000 & 0.905 \\
\hline POLYS & 6.150 & 9.260 & 0.000 & 2.170 \\
\hline
\end{tabular}

Table 3 Pearson correlation analysis

\begin{tabular}{|l|c|c|c|c|c|c|c|c|c|c|}
\hline & ARQ & EOCB & ROPM & EOLWF & SER & PMIS & POFO & IFRS & ISA & POLYS \\
\hline ARQ & 1.000 & & & & & & & & & \\
\hline EOCB & .784 & 1.000 & & & & & & & & \\
\hline ROPM & .880 & .809 & & & & & & & & \\
\hline EOLFW & .721 & .809 & 1.000 & 1.000 & & & & & & \\
\hline SER & .855 & .664 & .774 & .748 & 1.000 & & & & & \\
\hline PMIS & .908 & .785 & .849 & .810 & .837 & 1.000 & & & & \\
\hline POFO & .125 & .175 & .185 & .697 & .037 & .146 & 1.000 & & & \\
\hline IFRS & .069 & .045 & .016 & .185 & -.109 & -.019 & .073 & 1.000 & & \\
\hline ISA & .346 & .129 & .222 & .273 & .428 & .273 & .018 & .110 & 1.000 & \\
\hline POLYS & .563 & .440 & .569 & .278 & .541 & .457 & .111 & .206 & .410 & 1.000 \\
\hline N =234 & & & & & & & & & & \\
\hline
\end{tabular}

Table 3.1 Reporting collinearity statistics on pooled regression for Model 1

\begin{tabular}{|l|l|l|}
\hline \multicolumn{1}{|c|}{ Independent variable } & \multicolumn{1}{|c|}{ Tolerance } & \multicolumn{1}{c|}{ VIF } \\
\hline EOCB & .294 & 6.903 \\
\hline ROPM & .144 & 5.600 \\
\hline EOLFW & .179 & 7.172 \\
\hline SER & .139 & 1.368 \\
\hline PMIS & .731 & 1.092 \\
\hline POFO & .916 & 1.989 \\
\hline IFRS & .503 & 1.372 \\
\hline ISA & .729 & \\
\hline
\end{tabular}


POLYS

.675

1.482

ARQ is the dependent variable; Tolerance indicates how much the variability of the specified independent is not explained by the other independent variables in the model. If this value is greater than .10 it indicates that there is no multicollinearity. Variance inflation factor (VIF) is the inverse of the Tolerance value. Any VIF value greater than nine indicates multicollinearity (Field 2000; Hair et al. 2006).

Table 4 Regressions with and without US data

\begin{tabular}{|c|c|c|}
\hline Variables & $\begin{array}{l}\text { Model 1: Pooled } \\
\text { regression with US }\end{array}$ & Model 2: Regression without US \\
\hline \multirow[t]{3}{*}{ Constant } & - & - \\
\hline & 1.073 & 1.255 \\
\hline & .284 & .211 \\
\hline \multirow[t]{3}{*}{ PMIS } & .429 & .341 \\
\hline & 7.258 & 5.838 \\
\hline & $.001 * * *$ & $.000 * * *$ \\
\hline \multirow[t]{3}{*}{ EOLWF } & .032 & .036 \\
\hline & .594 & .601 \\
\hline & .553 & .567 \\
\hline \multirow[t]{3}{*}{ SER } & .260 & .236 \\
\hline & 5.006 & 4.548 \\
\hline & $.000 * * *$ & $.001 * * *$ \\
\hline \multirow[t]{3}{*}{ EOCB } & .098 & .034 \\
\hline & 2.451 & .858 \\
\hline & $.015^{* *}$ & .392 \\
\hline \multirow[t]{3}{*}{ ROPM } & .173 & .152 \\
\hline & 4.026 & 3.675 \\
\hline & $.000 * * *$ & $.000 * * *$ \\
\hline \multirow[t]{3}{*}{ IFRS } & .089 & .083 \\
\hline & 3.432 & 3.253 \\
\hline & $.001 * * *$ & $.001 * * *$ \\
\hline
\end{tabular}




\begin{tabular}{|l|l|l|}
\hline ISA & .046 & .050 \\
\hline & 1.693 & 1.893 \\
\hline POFO & $.092^{*}$ & $.060^{*}$ \\
\hline & .144 & .017 \\
\hline & 2.130 & .782 \\
\hline POLYS & $.043 * *$ & .435 \\
\hline & .045 & .031 \\
\hline Adjusted R-Square & .892 & 1.005 \\
\hline F-statistic & .150 & .316 \\
\hline$p$ values & 161.702 & .900 \\
\hline N & & 166.972 \\
\hline
\end{tabular}

This table presents the results of the following regressions.

Model 1: $A R Q=\beta_{0}+\beta_{1} E O F L W+\beta_{2} P M I S+\beta_{3} S E R+\beta 4 E C O B+\beta_{5} R O P M+\beta_{6} I F R S+\beta_{7} I S A+\beta_{8} P O F O+\beta_{9} P O L Y S+\varepsilon$

Model 2: $A R Q_{-U S}=\beta_{0}+\beta_{1} E O F L W_{U S}+\beta_{2} P M I S_{-U S}+\beta_{3} S E R_{U S}+\beta 4 E C O B_{-U S}+\beta_{5} R O P M V_{-U S}+\beta_{6} I F R S_{-U S}+\beta_{7} I S A_{2-U S}+\beta_{8} P O F O_{-U S}+\beta_{9}$ $P O L Y S_{-U S}+\varepsilon$

$\mathrm{ARQ}=$ Auditing and reporting quality; PMIS = Protection of minority interests; EOLFW = Efficiency of legal framework;

SER $=$ Securities Exchange regulations; $\mathrm{ECOB}=$ Efficacy of corporate board ROPM $=$ Reliance on professional management;

IFRS = International Financial Reporting Standards; ISA = International Standards on Auditing; POFO = Prevalence of foreign ownership;

POLYS $=$ Political systems. We report the regression coefficients in the order of beta values, $t$ values and $p$ values. ${ }^{* * *}, * *$ and $*$ denote statistical significance at the $1 \%, 5 \%$ and $10 \%$ levels respectively.

Table 5 Regressions on auditing and reporting quality

\begin{tabular}{|l|l|l|l|}
\hline \multicolumn{1}{|c|}{ Variables } & $\begin{array}{c}\text { Model 1: Pooled } \\
\text { regression (no fixed } \\
\text { effects) }\end{array}$ & $\begin{array}{c}\text { Model 3: Country } \\
\text { fixed effects }\end{array}$ & \multicolumn{1}{|c|}{ Model 4: Year fixed effects } \\
\hline Constant & - & - & - \\
\hline & 1.073 & 1.223 & 2.092 \\
\hline & .284 & .223 & .038 \\
\hline PMIS & .429 & .260 & .423 \\
\hline & 7.258 & 4.035 & 7.828 \\
\hline & $.001 * * *$ & $.000^{* * *}$ & $.000^{* * *}$ \\
\hline
\end{tabular}




\begin{tabular}{|c|c|c|c|}
\hline EOLWF & .032 & .045 & .049 \\
\hline & .594 & .603 & .610 \\
\hline & .553 & .771 & .783 \\
\hline \multirow[t]{3}{*}{ SER } & .260 & .355 & .310 \\
\hline & 5.006 & 7.150 & 6.092 \\
\hline & $.000 * * *$ & $.000 * * *$ & $.000 * * *$ \\
\hline \multirow[t]{3}{*}{ EOCB } & .098 & .144 & .105 \\
\hline & 2.451 & 2.282 & 2.824 \\
\hline & $.015 * * *$ & $.024 * *$ & $.005^{* *}$ \\
\hline \multirow[t]{3}{*}{ ROPM } & .173 & .102 & .186 \\
\hline & 4.026 & 2.467 & 4.653 \\
\hline & $.000 * * *$ & $.015^{* *}$ & $.000 * * *$ \\
\hline \multirow[t]{3}{*}{ IFRS } & .089 & .079 & .105 \\
\hline & 3.432 & 3.066 & 4.147 \\
\hline & $.001 * * *$ & $.002 * * *$ & $.000 * *$ \\
\hline \multirow[t]{3}{*}{ ISA } & .046 & .054 & .046 \\
\hline & 1.693 & 2.150 & 1.730 \\
\hline & $.092 *$ & $.033^{* *}$ & $.085 *$ \\
\hline \multirow[t]{3}{*}{ POFO } & .144 & .612 & .001 \\
\hline & 2.130 & 5.221 & .057 \\
\hline & $.043 * *$ & $.001 * * *$ & .954 \\
\hline \multirow[t]{3}{*}{ POLYS } & .045 & .023 & .034 \\
\hline & 1.443 & .783 & .891 \\
\hline & .150 & .434 & .545 \\
\hline Adjusted R-Square & .892 & .920 & .893 \\
\hline F-statistic & 161.702 & 66.75 & 115.643 \\
\hline$p$ values & 000 & 000 & 000 \\
\hline
\end{tabular}




\begin{tabular}{|l|c|c|c|}
\hline $\mathrm{N}$ & 234 & 234 & 234 \\
\hline
\end{tabular}

This table presents the results of the following regressions.

Model 3: $A R Q=\beta_{0}+\beta_{1} E O F L W+\beta_{2} P M I S+\beta_{3} S E R+\beta 4 E C O B+\beta_{5} R O P M+\beta_{6} I F R S+\beta_{7} I S A+\beta_{8} P O F O+\beta_{9} P O L Y S+Y E A R$ FIXED EFFECTS (3)

Model 4: $A R Q=\beta_{0}+\beta_{1} E O F L W+\beta_{2} P M I S+\beta_{3} S E R+\beta 4 E C O B+\beta_{5} R O P M+\beta_{6} I F R S+\beta_{7} I S A+\beta_{8} P O F O+\beta_{9} P O L Y S+C O U N T R Y$ FIXED EFFECTS (4)

$\mathrm{ARQ}=$ Auditing and reporting quality; PMIS = Protection of minority interests; EOLFW = Efficiency of legal framework; SER = Securities Exchange regulations; $\mathrm{ECOB}=$ Efficacy of corporate board; ROPM = Reliance on professional management; IFRS = International Financial Reporting Standards; ISA = International Standards on Auditing; POFO = Prevalence of foreign ownership; POLYS = Political systems. We report the regression coefficients in the order of beta values, $t$ values and $p$ values. The panel regressions are estimated using: (i) pooled regression with no effects; (ii) country fixed effects; and (iii) year fixed effects. ***, ** and * denote statistical significance at the $1 \%, 5 \%$ and $10 \%$ levels respectively.

Table 6 Regressions comparing developed and developing countries

\begin{tabular}{|c|c|c|}
\hline Variables & $\begin{array}{l}\text { Model 5: Developed } \\
\text { countries }\end{array}$ & Model 6: Developing countries \\
\hline \multirow[t]{3}{*}{ Constant } & - & - \\
\hline & 2.584 & .164 \\
\hline & .013 & .870 \\
\hline \multirow[t]{3}{*}{ PMIS } & .270 & .460 \\
\hline & 3.858 & 6.214 \\
\hline & $.000 * * *$ & $.000 * * *$ \\
\hline \multirow[t]{3}{*}{ EOLWF } & .132 & .0756 \\
\hline & 1.594 & .672 \\
\hline & $.035 * *$ & .579 \\
\hline \multirow[t]{3}{*}{ SER } & .326 & .246 \\
\hline & 3.867 & 3.441 \\
\hline & $.000 * * *$ & $.001 * * *$ \\
\hline \multirow[t]{3}{*}{ EOCB } & .171 & .057 \\
\hline & .600 & 1.286 \\
\hline & $.049 * *$ & .200 \\
\hline \multirow[t]{2}{*}{ ROPM } & .281 & .232 \\
\hline & 5.033 & 3.738 \\
\hline
\end{tabular}




\begin{tabular}{|c|c|c|}
\hline & $.000 * * *$ & $.000 * * *$ \\
\hline \multirow[t]{3}{*}{ IFRS } & .285 & .088 \\
\hline & 1.141 & 2.310 \\
\hline & $.001 * * *$ & $.022 * *$ \\
\hline \multirow[t]{3}{*}{ ISA } & .153 & .036 \\
\hline & 2.386 & .901 \\
\hline & $.021 * *$ & $.069 *$ \\
\hline \multirow[t]{3}{*}{ POFO } & .381 & .029 \\
\hline & 4.423 & .867 \\
\hline & $.000 * * *$ & .387 \\
\hline \multirow[t]{3}{*}{ POLYS } & .106 & .050 \\
\hline & 1.466 & 1.217 \\
\hline & .150 & .225 \\
\hline Adjusted R-Square & .915 & .811 \\
\hline F-Statistic & 64.335 & 77.878 \\
\hline $\mathrm{P}$ values & 000 & 000 \\
\hline $\mathrm{N}$ & 180 & 54 \\
\hline
\end{tabular}

This table presents the results of the following regressions. Model 5: $A R Q_{\text {developed }}=\beta_{0}+\beta_{1} E O F L W+\beta_{2} P M I S+\beta_{3} S E R+\beta 4 E C O B+\beta_{5} R O P M$ $+\beta_{6} I F R S+\beta_{7} I S A+\beta_{8}$ POFO $+\beta_{9}$ POLYS + YEAR FIXED EFFECTS (5)

Model 6: $A R Q_{\text {developing }}=\beta_{0}+\beta_{1} E O F L W+\beta_{2} P M I S+\beta_{3} S E R+\beta 4 E C O B+\beta_{5} R O P M+\beta_{6} I F R S+\beta_{7} I S A+\beta_{8} P O F O+\beta_{9} P O L Y S+C O U N T R Y$ FIXED EFFECTS (6)

$\mathrm{ARQ}=$ Auditing and reporting quality; PMIS = Protection of minority interests; EOLFW = Efficiency of legal framework; SER = Securities Exchange regulations; $\mathrm{ECOB}=$ Efficacy of corporate board; ROPM = Reliance on professional management; IFRS = International Financial Reporting Standards; ISA = International Standards on Auditing; POFO = Prevalence of foreign ownership; POLYS = Political systems. We

report the regression coefficients in the order of beta values, $t$ values and $p$ values. ${ }^{* * *}, * *$ and $*$ denote statistical significance at the $1 \%, 5 \%$ and $10 \%$ levels respectively.

\section{Appendix A Typical Survey Question on ARQ}

In your country, how would you assess financial auditing and reporting standards regarding company financial performance? 
Extremely weak $<1234567>$ Extremely strong

Circling 1 --- you agree completely with the answer on the left-hand side

Circling 2 --- you largely agree with the answer on left-hand side

Circling 3 --- you somewhat agree with the answer on the left-hand side

Circling 4 --- your opinion is indifferent between the two answers

Circling 5 --- you somewhat agree with the answer on right-hand side

Circling 6 --- you largely agree with the answer on the right-hand side

Circling 7 --- you agree completely with the answer on the right-hand side

Source: WEF Global Competitiveness Report 2009: 50.

Appendix B Twelve Pillars of the Global Competitiveness Index

\begin{tabular}{|l|c|c|}
\hline \multicolumn{1}{|c|}{ Pillars } & Description & Number of indicators \\
\hline 1 & Institution & 19 \\
\hline 2 & Infrastructure & 8 \\
\hline 3 & Macroeconomic stability & 5 \\
\hline 4 & Health and primary education & 11 \\
\hline 5 & Higher education and training & 8 \\
\hline 6 & Goods market efficiency & 15 \\
\hline 7 & Labour market efficiency & 9 \\
\hline 8 & Financial market sophistication & \\
\hline 9 & & \\
\hline 10 & Technological innovation & \\
\hline 11 & & \\
\hline
\end{tabular}




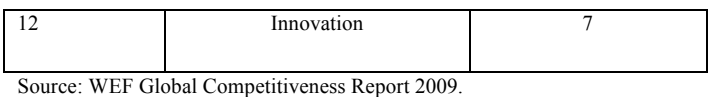

Source: WEF Global Competitiveness Report 2009

Appendix C Sample Distribution of WEF Survey Respondents

\begin{tabular}{|l|c|c|c|c|c|c|c|c|c|}
\hline \multicolumn{1}{|c|}{ Countries } & $\mathbf{2 0 0 7}$ & $\mathbf{2 0 0 8}$ & $\mathbf{2 0 0 9}$ & $\mathbf{2 0 1 0}$ & $\mathbf{2 0 1 1}$ & $\mathbf{2 0 1 2}$ & $\mathbf{2 0 1 3}$ & $\mathbf{2 0 1 4}$ & $\mathbf{2 0 1 5}$ \\
\hline Australia & 82 & 83 & 67 & 45 & 72 & 68 & 57 & 57 & 66 \\
\hline Bangladesh & 87 & 93 & 89 & 89 & 69 & 86 & 71 & 71 & 76 \\
\hline Brunei & 33 & 38 & 44 & 111 & 91 & 44 & 34 & 34 & 71 \\
\hline Cambodia & 75 & 79 & 93 & 79 & 100 & 77 & 93 & 93 & 79 \\
\hline Canada & 76 & 79 & 100 & 90 & 98 & 103 & 133 & 133 & 79 \\
\hline Chile & 102 & 104 & 77 & 84 & 75 & 78 & 130 & 130 & 143 \\
\hline China & 313 & 323 & 373 & 362 & 370 & 362 & 364 & 364 & 364 \\
\hline India & 139 & 141 & 120 & 103 & 248 & 122 & 85 & 85 & 211 \\
\hline Indonesia & 82 & 83 & 90 & 86 & 86 & 88 & 87 & 87 & 90 \\
\hline Japan & 142 & 148 & 150 & 134 & 105 & 111 & 115 & 115 & 64 \\
\hline Korea & 108 & 116 & 95 & 176 & 112 & 112 & 81 & 81 & 81 \\
\hline Madagascar & 98 & 100 & 101 & 83 & 86 & 92 & 157 & 157 & 99 \\
\hline Malaysia & 67 & 70 & 68 & 110 & 87 & 79 & 106 & 106 & 96 \\
\hline Mauritius & 43 & 44 & 58 & 73 & 95 & 91 & 77 & 77 & 56 \\
\hline Mongolia & 73 & 81 & 83 & 81 & 84 & 85 & 86 & 86 & 81 \\
\hline Nepal & 94 & 99 & 101 & 98 & 102 & 93 & 93 & 93 & 84 \\
\hline New Zealand & 42 & 43 & 47 & 43 & 51 & 55 & 37 & 37 & 41 \\
\hline Pakistan & 125 & 130 & 300 & 218 & 130 & 110 & 130 & 130 & 56 \\
\hline Peru & 81 & 84 & 89 & 86 & 88 & 83 & 79 & 79 & 85 \\
\hline Philippines & 53 & 59 & 39 & 82 & 93 & 132 & 95 & 95 & 120 \\
\hline Russia & 341 & 343 & 368 & 346 & 377 & 414 & 294 & 294 & 216 \\
\hline Singapore & 131 & 136 & 144 & 122 & 152 & 178 & 150 & 150 & 163 \\
\hline Sri Lanka & 91 & 97 & 100 & 98 & 105 & 105 & 100 & 100 & 97 \\
\hline Thailand & 82 & 83 & 86 & 59 & 55 & 75 & 86 & 86 & 101 \\
\hline United States & 196 & 200 & 404 & 437 & 422 & 397 & 598 & 598 & 369 \\
\hline Vietnam & 128 & 130 & 144 & 104 & 96 & 96 & 109 & 109 & 95 \\
\hline Total & $\mathbf{2 8 8 4}$ & $\mathbf{2 9 8 6}$ & $\mathbf{3 4 3 0}$ & $\mathbf{3 3 3 9}$ & $\mathbf{3 4 4 9}$ & $\mathbf{3 3 3 6}$ & $\mathbf{3 4 4 7}$ & $\mathbf{3 4 4 7}$ & $\mathbf{3 0 8 3}$ \\
\hline
\end{tabular}

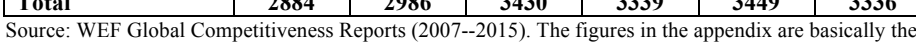

sample size surveyed with a completion rate of more than $50 \%$.

Appendix D ARQ Scores

\begin{tabular}{|l|l|l|l|l|l|l|l|l|l|}
\hline & $\mathbf{2 0 0 7}$ & $\mathbf{2 0 0 8}$ & $\mathbf{2 0 0 9}$ & $\mathbf{2 0 1 0}$ & $\mathbf{2 0 1 1}$ & $\mathbf{2 0 1 2}$ & $\mathbf{2 0 1 3}$ & $\mathbf{2 0 1 4}$ & $\mathbf{2 0 1 5}$ \\
\hline Australia & 6.2 & 6.0 & 5.8 & 5.9 & 5.8 & 5.9 & 6.0 & 5.8 & 5.8 \\
\hline Bangladesh & 3.3 & 3.6 & 3.8 & 3.8 & 3.8 & 3.8 & 3.7 & 3.6 & 3.6 \\
\hline Brunei & 4.9 & 5.1 & 5.0 & 4.8 & 5.0 & 4.8 & 4.8 & 5.0 & 5.0 \\
\hline Cambodia & 3.5 & 3.8 & 3.8 & 3.8 & 3.8 & 3.8 & 3.9 & 3.9 & 3.9 \\
\hline Canada & 6.1 & 6.1 & 6.1 & 6.2 & 6.1 & 6.2 & 6.1 & 6.0 & 6.0 \\
\hline Chile & 5.6 & 5.6 & 5.6 & 5.6 & 5.6 & 5.6 & 5.0 & 5.0 & 5.0 \\
\hline China & 4.4 & 4.7 & 4.8 & 4.8 & 4.8 & 4.8 & 4.5 & 4.5 & 4.5 \\
\hline India & 5.6 & 5.5 & 5.1 & 5.0 & 5.1 & 5.0 & 5.0 & 4.9 & 4.9 \\
\hline Indonesia & 4.6 & 4.6 & 4.6 & 4.3 & 4.6 & 5.0 & 4.4 & 4.6 & 4.6 \\
\hline Japan & 5.2 & 5.3 & 5.4 & 5.4 & 5.4 & 5.4 & 5.1 & 5.5 & 5.5 \\
\hline Korea & 5.3 & 4.9 & 4.3 & 4.3 & 4.3 & 4.3 & 4.5 & 4.3 & 4.3 \\
\hline Madagascar & 3.8 & 3.5 & 3.3 & 3.2 & 3.3 & 3.2 & 3.3 & 3.9 & 3.9 \\
\hline Malaysia & 5.5 & 5.2 & 5.4 & 5.6 & 5.4 & 5.6 & 5.4 & 5.4 & 5.4 \\
\hline
\end{tabular}




\begin{tabular}{|l|l|l|l|l|l|l|l|l|l|}
\hline Mauritius & 5.6 & 5.6 & 5.5 & 5.5 & 5.5 & 5.5 & 5.6 & 5.5 & 5.5 \\
\hline Mongolia & 3.6 & 3.7 & 3.8 & 3.9 & 3.8 & 3.9 & 3.6 & 3.4 & 3.4 \\
\hline Nepal & 3.6 & 3.7 & 4.0 & 3.9 & 4.0 & 3.9 & 3.9 & 3.8 & 3.8 \\
\hline New Zealand & 6.2 & 6.3 & 6.2 & 6.1 & 6.2 & 6.1 & 6.2 & 6.2 & 6.2 \\
\hline Pakistan & 4.8 & 4.4 & 4.2 & 4.2 & 4.2 & 4.2 & 4.4 & 4.4 & 4.4 \\
\hline Peru & 4.7 & 4.8 & 4.8 & 5.1 & 4.8 & 5.1 & 5.0 & 4.9 & 4.9 \\
\hline Philippines & 5.2 & 4.9 & 4.6 & 4.8 & 4.6 & 4.8 & 5.1 & 5.2 & 5.2 \\
\hline Russia Federation & 3.8 & 3.7 & 3.8 & 3.8 & 3.8 & 3.8 & 3.8 & 4.0 & 4.0 \\
\hline Singapore & 6.1 & 6.1 & 6.2 & 6.2 & 6.2 & 6.2 & 6.1 & 6.2 & 6.2 \\
\hline Sri Lanka & 5.3 & 4.3 & 5.2 & 5.1 & 5.2 & 5.1 & 5.0 & 5.1 & 5.1 \\
\hline Thailand & 5.0 & 5.0 & 5.1 & 4.9 & 5.1 & 4.9 & 4.9 & 5.1 & 5.1 \\
\hline United States & 5.9 & 5.3 & 5.0 & 5.2 & 5.0 & 5.2 & 5.2 & 5.3 & 5.3 \\
\hline Vietnam & 3.8 & 3.8 & 3.8 & 3.6 & 3.8 & 3.6 & 3.5 & 3.4 & 3.4 \\
\hline Average Score & 4.91 & 4.83 & 4.82 & 4.81 & 4.82 & 4.83 & 4.77 & 4.80 & 4.80 \\
\hline Sora: Glba Comptive
\end{tabular}

\begin{tabular}{llc} 
Average Score & 4.91 & 4.83 \\
\hline Source: Global Competitiveness Reports (2007--2015)
\end{tabular} 